Configurations of Power 
Digitized by the Internet Archive in 2018 with funding from

The Arcadia Fund 


\title{
CONFIGURATIONS OF POWER
}

\section{Holistic Anthropology} in Theory and Practice

\author{
E D I T E D B Y
}

John S. Henderson AND Patricia J. Netherly

Published in Cooperation with the Society for Latin American Anthropology and the American Anthropological Association

\section{Cornell University Press}


Copyright (C) I 993 by Cornell University

All rights reserved. Except for brief quotations in a review, this book, or parts thereof, must not be reproduced in any form without permission in writing from the publisher. For information, address Cornell University Press, Sage House, 5 I 2 East State Street, Ithaca, New York 14850.

First published 1993 by Cornell University Press.

International Standard Book Number 0-801 4-2487-9

Library of Congress Catalog Card Number 92-52759

Printed in the United States of America

Librarians: Library of Congress cataloging information appears on the last page of the book.

$($ The paper in this book meets the minimum requirements of the American National Standard for Information SciencesPermanence of Paper for Printed Library Materials, ANSI Z39.48-1984. 